\title{
The History of the Carey \\ Baptist College
}

Siong Ngor $\mathrm{Ng}$

2016 commemorates the $90^{\text {th }}$ Year anniversary of Carey Baptist College in Auckland, New Zealand. This article looks at the brief history of the library.

he intention to have the library started in 1924. It was recorded in the New Zealand Baptist (NZB), December 1924 p.274, that J.J. North wanted at once to

begin the formation of the college library. He states that he would like to begin to lay hands on necessary books, and would be grateful to those who would help him. It was amazing to note that the formation of the library was viewed as crucial as it was discussed and acted upon way before the college was of ficially established. Budget, the word that most of us are familiar with, was mentioned in $N Z B$, June 1925, p.145. It is stated that a donation of $\mathfrak{E} 5$ had been received for the purchase of books and in total over $\mathfrak{E} 7$ had been received. It was also noted that he was authorised to secure a sum of $£ 20$. A few months later, in September 1925, it was reported that Mr. E.R. James, of Auckland, had arranged for a set of Anti-Nicene Christian Writers to be placed on the shelves of the library (NZB1925, p. 227). Two months later in November, it was stated that the principal was busy collecting books for the library and it was viewed necessary to have as complete a theological and historical resource as possible ( $N Z B$ November 1925, p.282). It was also noted that J.J. North's own personal library was made available for college use. Some of the books that belonged to him are still currently in the library.

The library was housed at Mt Hobson in a lecture room in the basement. (Fig.1) 


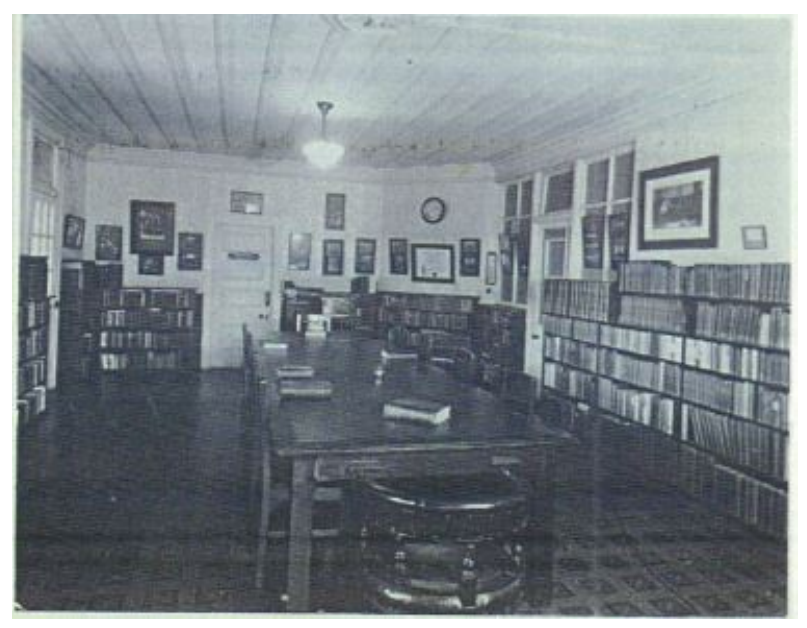

Fig.1

With donations and loans from various people, the collection size slowly increased. Bob Thomson, who was in his first year at the college and who later became the Principal, expressed his concerns about the library to E.M. Blaiklock. He stated that "the college library to my mind is deficient in solid conservative literature but $\mathrm{Mr}$. Blaiklock is trying to remedy that"1. Books were issued manually to staff and students. The circulation process was recorded in a book. (Fig.2)

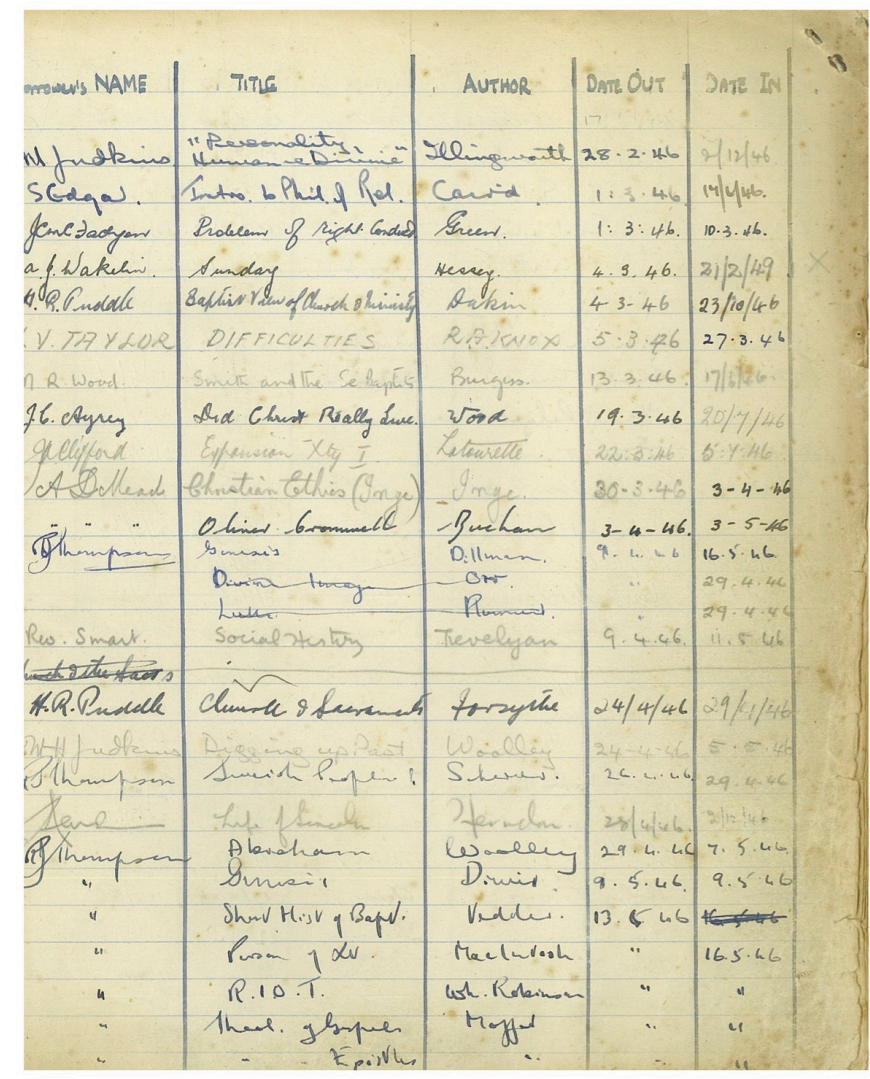

Fig.2

${ }^{1}$ According to a source provided by Lesley Utting. 
In July 1949, Roy Bullen, a student at the college, wrote a letter to the General Secretary of the Baptist Union. He suggested that the union establish a museum in order to preserve the Baptist heritage ${ }^{2}$. The following year the historical society was established and Bullen was appointed as the curator for the archive. It was noted in the $N Z B$, September 1951, p.235, that Bullen was actively seeking suitable resources of historical value to be added into the archive. John Maxwell Barker later took on the curator position from 1955-1986. To honour his memory, the archive was later named after him ${ }^{3}$.

In 1954, the college moved to 63 Victoria Avenue, Remuera ${ }^{4}$. The large house and about four acres were purchased for $£ 18,500^{5}$. The library, two lecture rooms, offices and dining room were on the ground floor ${ }^{6}$. When J. Ayson Clifford became the Principal in 1961, he catalogued the books with the help of some students. The large room was later inadequate for the number of volumes and the insufficient shelves and area for the students to study was a concern ${ }^{7}$. For a number of years there had been a discussion about the new library facility. A growing collection of books meant that the stacks were encroaching on the teaching space ${ }^{8}$. New shelving could only go so far to alleviate the pressure as they were expecting a collection from E.P.Y. Simpson to arrive $^{9}$. A deadline of 1970 was agreed for a new purpose-built library to be constructed $^{10}$. Unfortunately it took another 6 years before the new library building was opened as a stand-alone building. In March 1976, the new library building was dedicated as part of the Jubilee celebrations. The library was situated on the "northern side of Hobson House and joined to it at the level of its ground floor by a covered way"ll. The library included a mezzanine floor for additional stacks and a full basement for storage. It was planned to store up to 30,000 volumes of resources which was ambitious as the stock in 1974 was only 13,000. However, the management team

\footnotetext{
2 Don Dickson, "New Zealand Baptist Research and Historical Society," American Baptist Quarterly22, no. 3 (2003): 336.

${ }^{3}$ Ibid.

${ }^{4}$ Martin Sutherland and Laurie Guy, An Unfolding Story: A History of Carey Baptist College (Auckland: Archer Press, 2014), 106.

${ }^{5}$ Martin Sutherland, "Hesitating Too Long: the New Zealand Baptist College, 1952-1974," Pacific Journal of Baptist Research 6, no. 2(2010): 38.

${ }^{6}$ Ibid.

${ }^{7}$ E.F.Sherburd and A.L.Silcock, 18,000 Yesterdays (Auckland: Institute Press, [1976]), 35.

${ }^{8}$ Sutherland and Guy, An Unfolding Story, 141.

${ }^{9}$ According to the source provided by Lesley Utting.

${ }^{10}$ Sutherland and Guy, An Unfolding Story, 141.

${ }^{11}$ Sherburd and Silcock, 18,000 Yesterdays, 36. 
projected that the collection would double every seventeen years ${ }^{12}$. In honour of Ayson Clifford's contribution, the library was named after him on his retirement.

Like most libraries during that period, a card catalogue was used to list information about the resources held in the library. Brian and Shirley Smith, along with some students, transferred the information from the card catalogue to the library database in 1989.

The library moved again when the college purchased the current site. However, the library resources were inside containers and not accessible for 5 months as the development and renovation were happening. The college officially re-opened on 19 June $1994^{13}$. Brian Smith, the Principal at that time, recognised the value of the archive. He believed that it should be part of the new library and space was allocated for it ${ }^{14}$. Since his retirement, Brian has remained involved in the college community life. He started scanning the $N Z B$ from its beginning in 1876. It is now available digitally and is often used by researchers and students. That process started in 2004 and was completed in 2011.

Other than maintaining the physical collection, Lesley Utting, the librarian at that time, oversaw the implementation of the library resources to be added to the National Library's Catalogue (Te Puna) in 1997. At that same time, the college also joined the national interloan scheme that allows borrowing and loaning of resources to other libraries ${ }^{15}$. Strong relationships and networks were formed among the theological librarians as the college library was a member of the Australia and New Zealand Theological Library Association (ANZTLA).

In 2001, an online catalogue accessible remotely and onsite was implemented. New updates and new versions of the online catalogue happen on a regular basic. Ebooks were first introduced in 2009. Three titles were purchased initially. Students, especially distance students, appreciated the ability to access eBooks remotely. By 2016, the eBooks collection has grown to 358 titles. On top of that, the library also subscribes to eBook Religion database which consists of 6,700 titles. Another major improvement is the single platform for library users to search the library resources. Discovery, a web-based-system that allows users to search multiple databases, journal

${ }^{12}$ Sutherland and Guy, An Unfolding Story, 154.

${ }^{13}$ Sutherland and Guy, An Unfolding Story, 193.

${ }^{14}$ Angus MacLeod, "Making Yesterday Service the Cause of Tomorrow: 50 Years of the Historical Society," The New Zealand Journal of Baptist Research 6 (2001): 13.

${ }^{15}$ Sutherland and Guy, An Unfolding Story, 199. 
articles and the library catalogue, was implemented in 2015. For the first time, authentication software was also implemented during that time. It enables secure access to online resources for the staff and students.

In 2016 and 2017, the study areas on the mezzanine floor were redeveloped. New desks, chairs, carpet, and paint were added making it look spacious and inviting. Portable furniture such as stand-up desk and modular furniture make it possible to have flexible group spaces. Students are now able to configure their own space for collaborative work.

\section{Bibliography}

Dickson, Don. "New Zealand Baptist Research and Historical Society." American Baptist Quarterly22, no. 3 (2003):334-340.

MacLeod, Angus. "Making Yesterday Service the Cause of Tomorrow: 50 Years of the Historical Society." The New Zealand Journal of Baptist Research 6 (2001):3-28.

Sherburd, E. F. and A.L. Silcock. 18,000 Yesterdays. Auckland: Institute Press, [1976].

Sutherland, Martin and Laurie Guy. An Unfolding Story: A History of Carey Baptist College. Auckland: Archer Press, 2014.

Sutherland, Martin. "Hesitating Too Long: the New Zealand Baptist College, 19521974." Pacific Journal of Baptist Research 6, no. 2(2010):31-66. 